\title{
SURVEY ON THE MATHEMATICAL MODEL OF ALUMINIUM ALLOYS IN WELDING FOR AEROSPACE APPLICATIONS
}

\author{
Mr.RAMESH.M(AP-MECH), ALAN. CHRISTOPHER .B, ARAVIND 。 R \\ Department of mechanical engineering \\ Sri Ramakrishna Engineering College cbe-22.
}

Abstract :- The alloys in which aluminium is the predominant metal are called aluminium alloys.Alloys composed mostly of aluminium have been very important in aerospace manufacturing since the introduction of metal-skinned aircraft. Aluminum and its alloys can be joined by numerous methods than any other metal, but aluminum has various chemical and physical properties that need to be understood when using the various joining processes.A mathematical model is a description of a domain using mathematical concepts and language. The steps to develop a mathematical model is termed mathematical modeling.Mathematical models can take many forms, including dynamical systems, statistical models, differential equations. This paper reviews various configurations of aluminium alloys mathematical models along with their merits and demerits.

\section{INTRODUCTION}

The increase of aluminum within the welding fabrication industry, and its acceptance as the best alternative to steel for many applications, there are various requirements for those involved with developing aluminum projects to become more familiar with aluminium alloys. Today's aluminum alloys, together with their alternative tempers, comprise a wide and versatile range of manufacturing materials. For optimum component design and successful welding procedure development, it is important to comprehend the differences between the many alloys available and their various performance and weldability characteristics. When developing arc welding steps for these different alloys, consideration must be given to the particular alloy being welded.

The Benefits of using Aluminum

- Aluminum is a light metal and the third of the density of steel, copper, and brass.

- Aluminum has great corrosion resistance to common atmospheric and marine atmospheres. Its corrosion resistance and scratch resistance can be strengthened by anodizing.

- Aluminum has more reflectivity and can be used for decorative applications.

- Some aluminum alloys could match or even go beyond the strength of common construction steel.

- Aluminum retains its toughness at minimal temperatures, without becoming brittle like carbon steels.

- Aluminum is a very good conductor of heat and electricity. When measured by equal crosssectional area, electrical grade aluminum has conductivity which is approximately $68 \%$ of electrical grade annealed copper. Also, when compared using equal weight, the conductivity of aluminum is $208 \%$ of copper. 
- Aluminumis processed and formed using a wide variety of forming processes including deep- drawing and roll forming.

- Aluminum is non-toxic and is normally used in contact with foodstuffs.

- Aluminum can be recycled and regenerated.

Mathematical modelling can help us improve our understanding of the real world as certain variables can readily be changed.

\section{MATHEMATICAL MODELING}

Mathematical models are significant in the natural sciences, particularly in physics. Physical theories are always expressed using mathematical models. Throughout history, more and more accurate mathematical models have been developed.A mathematical model usually defines a system by a set of variables and a set of equations that establish relationships between the variables. Variables could be of many types; real or integer numbers, boolean values or strings, for example. The variables represent some properties of the system, for example, measured system outputs often in the form of signals, timing data, counters, and event occurrence (yes/no). The actual model is the set of functions that indicate the relations between the various variables.

\section{MODELING DIAGRAM}

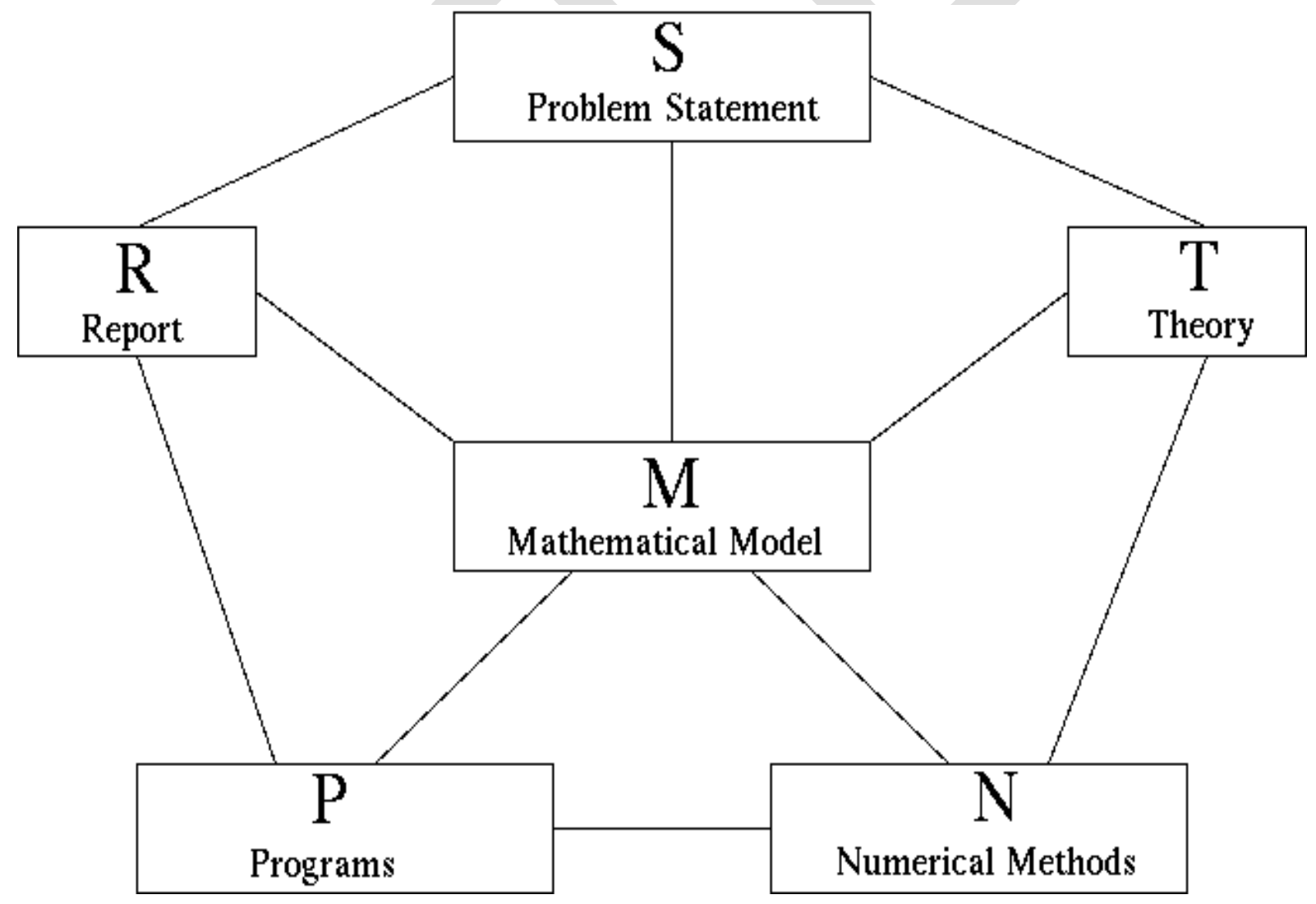




\section{WELDING}

Today fusion welding is the most significant technique used in welding construction.Fusion welding is defined as a joining process of two metals of similar composition accomplished by fusion.Most common welding processes in the arc welding category is as follows:

- Friction Stir Welding (FSW)

- Gas Tungsten Arc Welding (GTAW)

- Gas Metal Arc Welding (GMAW)

- Submerged Arc Welding (SAW)

- Electroslag Welding (ESW)

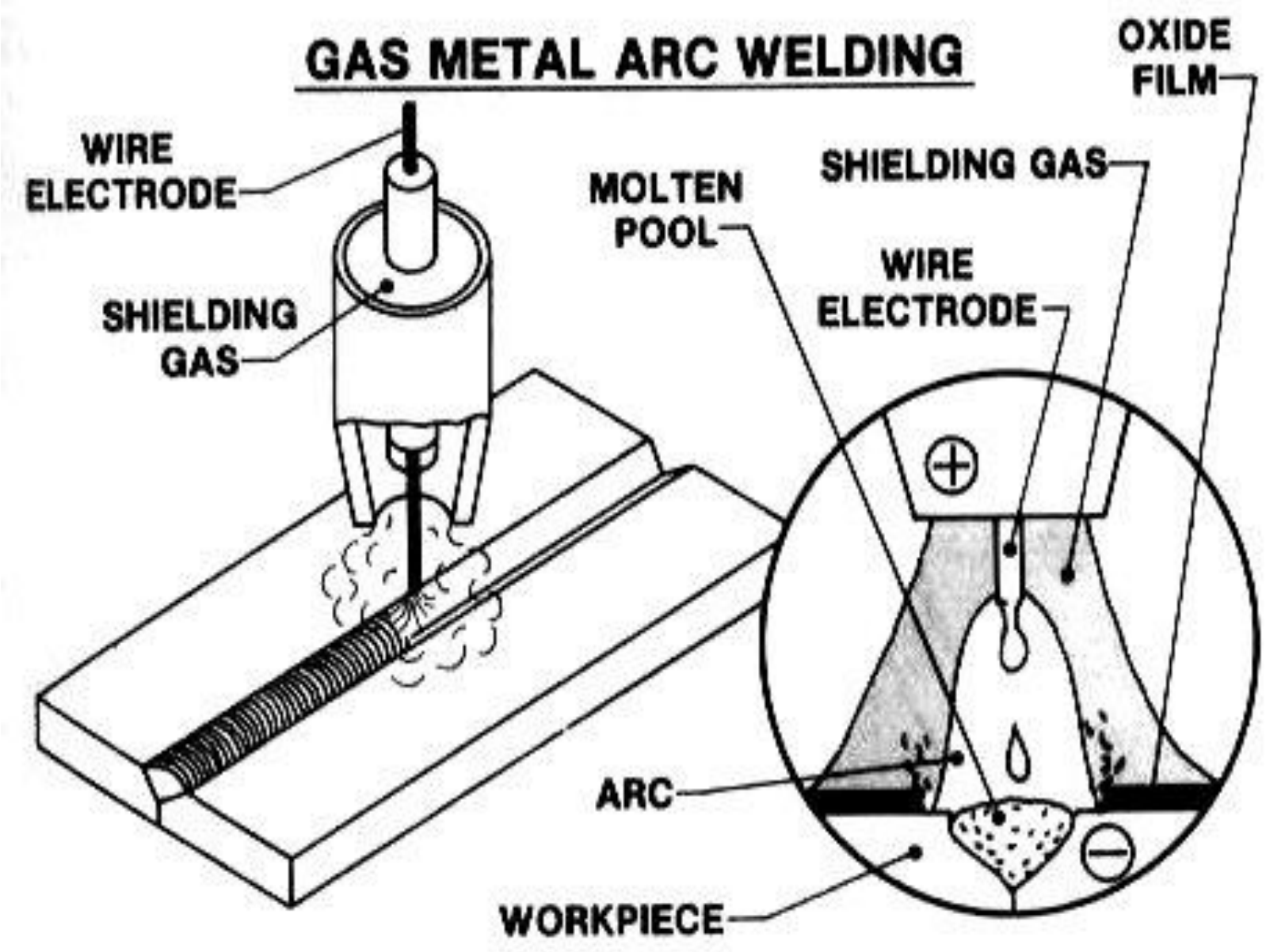

GMAW is a welding process in which an electric arc forms between a consumable wire electrode and the workpiece metal, which heats the workpiece metal, causing them to melt and join. 


\section{FRICTION STIR WELDING:}

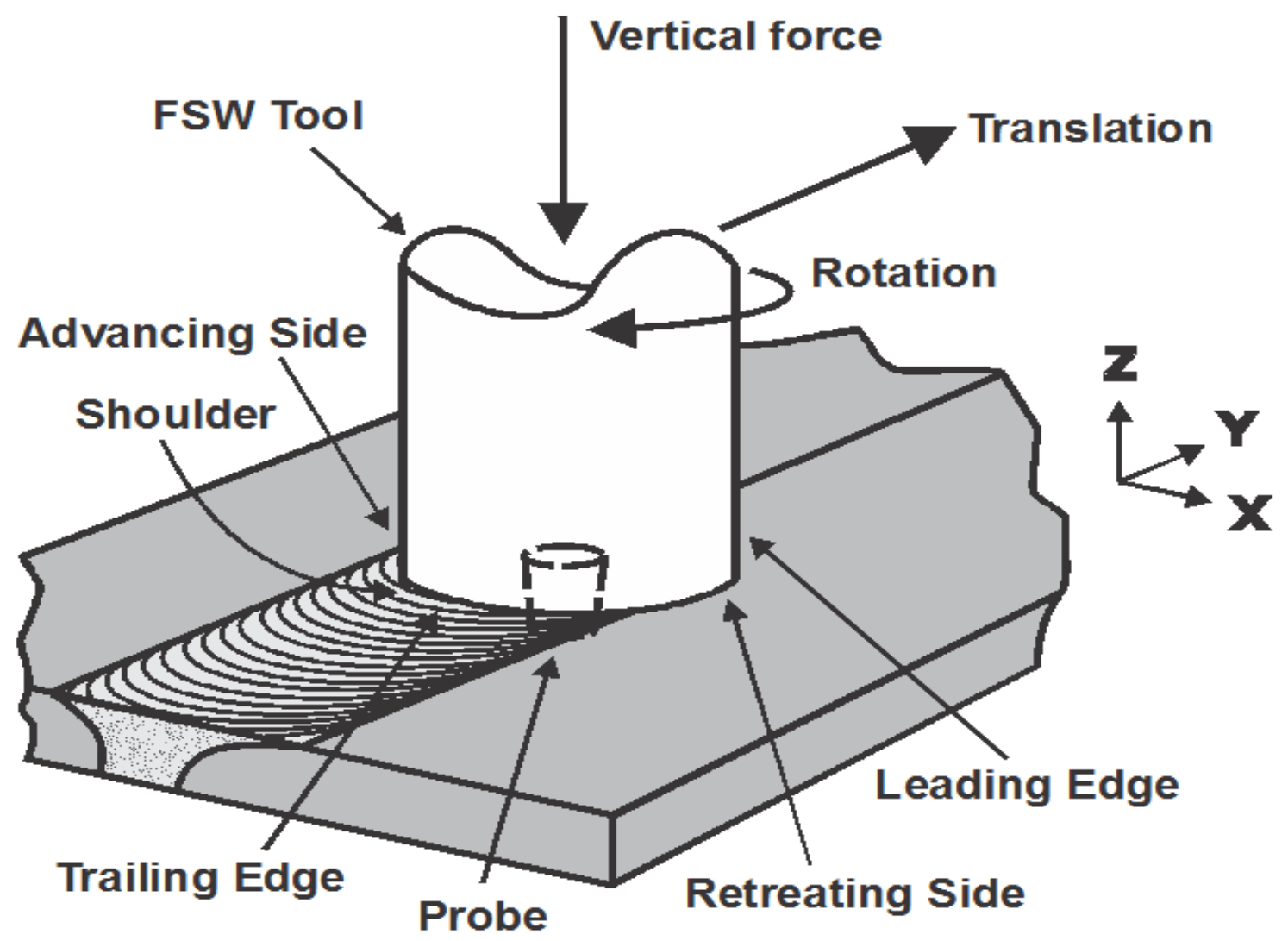

Friction stir welding is a solid-state linking process that uses a non-consumable electrode to two facing metals without melting the workpiecematerial.Heat is generated by friction between the rotating tool and the workpiece material, which leads to a softened region near the FSW tool. As the tool is traversed along the joint line, it mechanically mixes the two pieces of metal, and forges the softened metal and the hot by the mechanical pressure, which is applied by the tool.FSW is also found in modern shipbuilding, trains, and aerospace applications.

Friction stir welding is hence both a deformation process and a thermal process, even though there is no bulk fusion. The maximum temperature reached is a matter of some debate. Thermocouple measurements during FSW of aluminium alloys suggest that, in general, the temperature stays below $480^{\circ} \mathrm{C}$.

\section{LITERATURE REVIEW}

\begin{tabular}{|l|l|l|l|}
\hline SNO & TITLE OF THE PAPER & AUTHOR & REMARKS \\
\hline 1. & $\begin{array}{l}\text { Finite element modelling } \\
\text { simulation of transverse } \\
\text { welding phenomenon in } \\
\text { aluminium extrusion process }\end{array}$ & $\begin{array}{l}\text { Qiang Li, Chris } \\
\text { Harris, } \\
\text { R.Jolly }\end{array}$ & Mark \\
& & $\begin{array}{l}\text { The formation and metal flow } \\
\text { behaviour of transverse welds in the } \\
\text { aluminium extrusion process have } \\
\text { been } \\
\text { solved using an FEM simulation } \\
\text { process.It was shown that } \\
\text { inhomogeneous metal flow occurred. }\end{array}$ \\
\hline
\end{tabular}




\begin{tabular}{|c|c|c|c|}
\hline & & & $\begin{array}{l}\text { The welding interface sliding has } \\
\text { occurred in the transverse welding } \\
\text { process and there is a welding point } \\
\text { where materials start to adhere } \\
\text { together.The } \\
\text { characteristics at the die corner } \\
\text { affects the welding length. }\end{array}$ \\
\hline 2 & $\begin{array}{l}\text { An experimental analysis } \\
\text { and optimization of process } \\
\text { parameter on } \\
\text { friction stir welding of AA } \\
6061 \text {-T6 aluminum alloy } \\
\text { using RSM }\end{array}$ & $\begin{array}{l}\text { G.Elatharasan,V.S. } \\
\text { Senthil Kumar. }\end{array}$ & $\begin{array}{l}\text { In this study, the UTS, YS and TE in } \\
\text { FSW process were modelled and } \\
\text { analyzed through response surface } \\
\text { methodology (RSM). A central } \\
\text { composite design (CCD) in RSM } \\
\text { consisting of three variables. } \\
\text { Rotational speed, } \\
\text { traverse speed and axial force have } \\
\text { been employed to carry out the } \\
\text { experimental study. } \\
\text { - Empirical relationship were } \\
\text { developed to estimate the } \\
\text { UTS,YS and TE of friction } \\
\text { stir welded AA 6061-T6 } \\
\text { aluminium alloy. } \\
\text { UTS and YS of the FS } \\
\text { welded joints increased with } \\
\text { the increase of tool rotational } \\
\text { speed, welding speedand tool } \\
\text { axial force up to a maximum } \\
\text { value, and then decreased. } \\
\text { A maximum tensile strength } \\
\text { of } 197.50 \text { MPa, Yield } \\
\text { strength of } 175.25 \mathrm{MPa} \text { and } \\
\% \text { of Elongation of } 6.96 \text { was } \\
\text { exhibited by the FSW joints } \\
\text { with } 30 \mathrm{~mm} / \mathrm{min} \text { welding } \\
\text { speed. }\end{array}$ \\
\hline 3 & $\begin{array}{l}\text { Development } \\
\text { mathematical model to } \\
\text { predict the mechanical } \\
\text { properties of friction stir } \\
\text { welded AA6351 aluminum } \\
\text { alloy. }\end{array}$ & $\begin{array}{l}\text { R. Palanivel, P. } \\
\text { Koshy Mathews } \\
\text { and N. Murugan }\end{array}$ & $\begin{array}{l}\text { 1. The relationships between process } \\
\text { parameters for FS welding of } \\
\text { aluminum alloy have been } \\
\text { established. The response surface } \\
\text { methodology was adopted to } \\
\text { develop the regression models, } \\
\text { which were checked for their } \\
\text { adequacy using ANOVA } \\
\text { test, scatter diagrams and found to } \\
\text { be satisfactory. } \\
\text { 2. Confirmation experiments showed } \\
\text { the developed models are } \\
\text { reasonably accurate. } \\
\text { 3. The increasing of tool rotational }\end{array}$ \\
\hline
\end{tabular}




\begin{tabular}{|c|c|c|c|}
\hline & & & $\begin{array}{l}\text { speed, welding speed and axial force } \\
\text { leads to the increase in the ultimate } \\
\text { tensile strength; and it reaches a } \\
\text { maximum value and then decreases. } \\
\text { This trend } \\
\text { is common for yield strength and } \\
\text { percentage of elongation. }\end{array}$ \\
\hline 4. & $\begin{array}{l}\text { Finite element modelling of } \\
\text { heat flow in deep } \\
\text { penetration laser welds in } \\
\text { aluminium alloys. }\end{array}$ & $\begin{array}{l}\text { N. Sonti and M. F. } \\
\text { Amateau }\end{array}$ & $\begin{array}{l}\text { A two-dimensional nonlinear } \\
\text { transient finite-element heat transfer } \\
\text { model was developed } \\
\text { to model the heat flow in welding. } \\
\text { The model was tested for stability } \\
\text { and accuracy by solving several heat } \\
\text { conduction problems involving } \\
\text { phase change. The model was } \\
\text { used to simulate the melting and } \\
\text { solidification phenomena occurring } \\
\text { in aluminum laserwelds and to } \\
\text { predict the three-dimensional shape } \\
\text { of the weld pool and the shape of the } \\
\text { mushy zone during solidification. } \\
\text { The predicted weld bead shape and } \\
\text { dimensions are in good agreement } \\
\text { with the experimental results. The } \\
\text { model also predicted local } \\
\text { solidification times and thereby the } \\
\text { secondary dendrite arm spacings } \\
\text { with reasonable accuracy. }\end{array}$ \\
\hline 5. & $\begin{array}{l}\text { Modelling of friction stir } \\
\text { welding of } 7 \mathrm{xxx} \text { aluminium } \\
\text { alloys }\end{array}$ & $\begin{array}{lr}\text { N. } & \text { Kamp, } \\
\text { A.Sullivan, } & \text { J.D. } \\
\text { Robson } & \end{array}$ & $\begin{array}{l}\text { A combined modelling approach has } \\
\text { been applied to two high strength } \\
7000 \text { alloys subjected to friction stir } \\
\text { welding and post weld heat } \\
\text { treatments. A microstructural model } \\
\text { was used to determine the } \\
\text { precipitation mechanisms associated } \\
\text { with specific thermal cycles/weld } \\
\text { zones. The microstructural model } \\
\text { precipitate distribution predictions } \\
\text { were in good agreement with the } \\
\text { measured particle sizes over large } \\
\text { areas of the } \\
\text { weld. However, the solute remaining } \\
\text { in solution after the heat up stage of } \\
\text { the FSW is expected to be accurately } \\
\text { predicted by the model. As such, the } \\
\text { driving force for further precipitation } \\
\text { and alloy strengthening is contained } \\
\text { in the model } \\
\text { prediction. }\end{array}$ \\
\hline
\end{tabular}




\begin{tabular}{|c|c|c|c|}
\hline 6. & $\begin{array}{l}\text { A conceptual model for the } \\
\text { process variables related to } \\
\text { heat generation in friction } \\
\text { stir welding of aluminum }\end{array}$ & $\begin{array}{l}\text { Kevin J.Colligana, } \\
\text { and Rajiv S. Mishra }\end{array}$ & $\begin{array}{l}\text { This review proposes a conceptual } \\
\text { model of the mechanisms of heat } \\
\text { generation in FSW } \\
\text { for the purpose of facilitating a } \\
\text { general understanding } \\
\text { of the process. In } \\
\text { addition, quantitative study of the } \\
\text { effects of differentvariables could } \\
\text { lead to assigning weighting factors } \\
\text { to } \\
\text { the interactions between variables. } \\
\text { This work yields valuable insight } \\
\text { into the relative magnitude of the } \\
\text { role of friction vs. plastic work in } \\
\text { heat generation and the relative } \\
\text { importance of strain } \\
\text { rate effects. }\end{array}$ \\
\hline 7. & $\begin{array}{l}\text { Mathematical model of } \\
\text { deformation and } \\
\text { microstructural evolution } \\
\text { during hot rolling } \\
\text { of aluminium alloy } 5083\end{array}$ & $\begin{array}{l}\text { M. A. Wells, D. M. } \\
\text { Maijer, S. Jupp, G. } \\
\text { Lockhart and M. R. } \\
\text { van der Winden }\end{array}$ & $\begin{array}{l}\text { A mathematical model to predict the } \\
\text { thickness temperature, strain and } \\
\text { strain rate distribution during hot } \\
\text { rolling and microstructure evolution } \\
\text { was developed using ABAQUS. } \\
\text { The simulation of the friction } \\
\text { conditions between the } \\
\text { strip and the work roll using a } \\
\text { friction coefficient of } 0.3 \text { is shown } \\
\text { by the strain measurements. } \\
\text { The gradient in fraction } \\
\text { recrystallised measured } \\
\text { through the thickness of the strip is a } \\
\text { direct result of the } \\
\text { temperature gradient experienced by } \\
\text { the strip during the } \\
\text { rolling operation. }\end{array}$ \\
\hline 8. & $\begin{array}{l}\text { Analysis of Aluminum } \\
\text { Resistance Spot } \\
\text { Welding Processes Using } \\
\text { Coupled Finite Element } \\
\text { Procedures }\end{array}$ & $\begin{array}{l}\text { X. SUN AND P. } \\
\text { DONG }\end{array}$ & $\begin{array}{l}\text { A detailed case study on } \\
\text { welding of the 5xxx series of } \\
\text { aluminum alloys } \\
\text { is presented. The results are given } \\
\text { below: } \\
\text { The interfacial contact behavior in } \\
\text { the form of contact area change } \\
\text { duringwelding time plays a critical } \\
\text { role in the } \\
\text { nugget formation process in welding } \\
\text { aluminum } \\
\text { alloys. } \\
\text { - The predicted pressure and } \\
\text { temperature } \\
\text { evolution histories on the } \\
\text { electrode-sheet interface }\end{array}$ \\
\hline
\end{tabular}




\begin{tabular}{|c|c|c|c|}
\hline & & & $\begin{array}{l}\text { offer fundamental } \\
\text { understanding of electrode } \\
\text { pitting and } \\
\text { alloy formation mechanisms. } \\
\text { - It is found that, within the } \\
\text { range analyzed, } \\
\text { lesser electrode force or } \\
\text { higher welding current } \\
\text { generates a bigger } \\
\text { nugget. } \\
\text { Weld residual stresses and } \\
\text { final sheet deformation are } \\
\text { found as measures of weld } \\
\text { quality. }\end{array}$ \\
\hline 9. & $\begin{array}{l}\text { Developing } \\
\text { mathematical } \\
\text { models to predict tensile } \\
\text { properties } \\
\text { of pulsed current gas } \\
\text { tungsten arc welded } 6 \mathrm{Al}- \\
\text { 4V-Ti alloy. }\end{array}$ & $\begin{array}{l}\text { M. } \\
\text { Balasubramanian, } \\
\text { V. Jayabalan, } \\
\text { V. } \\
\text { Balasubramanian. }\end{array}$ & $\begin{array}{l}\text { Mathematical models have been } \\
\text { produced to predict the tensile } \\
\text { properties of pulsed current GTA } \\
\text { welded } \\
6 \mathrm{Al}-4 \mathrm{~V}-\mathrm{Ti} \text { alloy incorporating } \\
\text { pulsed current parameters. } \\
\text { The obtained models can be } \\
\text { effectively used to find the tensile } \\
\text { properties of pulsed current GTA } \\
\text { welded 6Al-4V-Ti alloy within the } \\
\text { range of parameters considered for } \\
\text { investigation. }\end{array}$ \\
\hline 10. & $\begin{array}{l}\text { Predicting tensile strength of } \\
\text { friction stir welded AA6061 } \\
\text { aluminium alloy joints } \\
\text { by a mathematical model }\end{array}$ & $\begin{array}{l}\text { K. Elangovan, } \\
\text { V. Balasubramanian } \\
\text {, S. Babu }\end{array}$ & $\begin{array}{l}\text { A mathematical model has been } \\
\text { produced to predict the tensile } \\
\text { strength of friction stir welded } \\
\text { AA6061 aluminium alloy joints } \\
\text { by incorporating welding parameters } \\
\text { and tool profiles using statistical } \\
\text { tools such as design of experiments, } \\
\text { analysis of variance and regression } \\
\text { analysis. } \\
\text { The joints developed using square } \\
\text { pin profiled tool with a rotational } \\
\text { speed of } 1200 \mathrm{rpm} \text {, welding speed of } \\
1.25 \mathrm{~mm} / \mathrm{s} \text { and axial } \\
\text { force of } 7 \mathrm{kN} \text { exhibited superior } \\
\text { tensile properties compared to } \\
\text { other joints }\end{array}$ \\
\hline 11. & $\begin{array}{l}\text { Experimental and numerical } \\
\text { investigation on under-water } \\
\text { friction stir } \\
\text { welding of armour grade } \\
\text { AA2519-T87 aluminium } \\
\text { alloy }\end{array}$ & $\begin{array}{l}\text { S.Sreesabari, } \\
\text { S.Malarvizhi, } \\
\text { V.Balasubramanian. }\end{array}$ & $\begin{array}{l}\text { The experimental investigation on } \\
\text { underwater friction stir welding } \\
\text { (UWFSW) and friction stir welding } \\
\text { (FSW) of armour grade, high } \\
\text { strength AA2519-T87 aluminium } \\
\text { alloy was preformed and conclusions }\end{array}$ \\
\hline
\end{tabular}




\begin{tabular}{|c|c|c|c|}
\hline & & & $\begin{array}{l}\text { are: } \\
\text { The peak temperature experienced } \\
\text { by the UWFSW jointis } 547{ }^{\circ} \mathrm{C} \\
\text { which is higher compared to the } \\
\text { peak temperature experienced by } \\
\text { FSW joint. } \\
\text { Also, UWFSW joint } \\
\text { resulted in higher cooling rate and } \\
\text { higher temperature gradient than } \\
\text { FSW joint. } \\
\text { The coarsening and dissolution of } \\
\text { precipitates proved TMAZ as the } \\
\text { weaker zone. } \\
\text { Under water FSW joint resulted in } \\
\text { higher tensile strength of } 271 \mathrm{MPa} \\
\text { and higher joint efficiency of } 60 \% \\
\text { than conventional } \\
\text { FSW joint.The controlling of } \\
\text { thermal histories } \\
\text { and its corresponding effect on } \\
\text { precipitation behaviour are } \\
\text { the main reasons for } \\
\text { strengthening the UWFSW joints. }\end{array}$ \\
\hline 12. & $\begin{array}{l}\text { Mathematical model and } \\
\text { optimization for underwater } \\
\text { friction stir welding } \\
\text { of a heat-treatable aluminum } \\
\text { alloy }\end{array}$ & $\begin{array}{l}\text { Huijie Zhang } \\
\text { Huijie Liu }\end{array}$ & $\begin{array}{l}\text { Based on the this study, the results } \\
\text { of significance } \\
\text { are as follows: } \\
\text { (1) A mathematical relationship } \\
\text { between tensile strength and } \\
\text { welding parameters is obtained to } \\
\text { predict the tensile strength of } \\
\text { underwater friction stir welded } \\
\text { 2219-T6 aluminumalloy. The } \\
\text { variance analysis indicates that the } \\
\text { rotation speed and } \\
\text { the welding speed are main factors } \\
\text { that affect the tensile strength. } \\
\text { (2) The effects of welding } \\
\text { parameters on tensile strength of the } \\
\text { UWFSW are ascertained } \\
\text { analyzing the developed } \\
\text { model, and the intrinsic reasons for } \\
\text { these effects are also discussed. } \\
\text { (3) The optimization result indicates } \\
\text { that a maximum tensile } \\
\text { strength of } 360 \text { MPa can be obtained } \\
\text { through underwater } \\
\text { FSW, which is checked by the } \\
\text { experimental result. This value is } 6 \%\end{array}$ \\
\hline
\end{tabular}




\begin{tabular}{|c|c|c|c|}
\hline & & & $\begin{array}{l}\text { higher than the maximum tensile } \\
\text { strength obtained in conventional } \\
\text { FSW. The controlling of temperature } \\
\text { histories and microstructural } \\
\text { evolutions is found to be the intrinsic } \\
\text { reason } \\
\text { forstrengthening the underwater } \\
\text { FSW. }\end{array}$ \\
\hline 13. & $\begin{array}{l}\text { Numerical modelling of the } \\
\text { material flow during } \\
\text { extrusion ofaluminium } \\
\text { alloys and transverse weld } \\
\text { formation }\end{array}$ & $\begin{array}{l}\text { YahyaMahmoodkha } \\
\text { nia, Mary A. Wells, } \\
\text { Nick Parson, W.J. } \\
\text { Poole }\end{array}$ & $\begin{array}{l}\text { The extrusion ratio plays a vital role } \\
\text { in the transverseweld length. As } \\
\text { expected as the extrusion ratio } \\
\text { increased thelength of the transverse } \\
\text { weld increased. } \\
\text { The effect of feeder geometry had a } \\
\text { major impact on the size of dead } \\
\text { metal zone andlength and thickness } \\
\text { of the transverse weld in the } \\
\text { extrudate. } \\
\text { Using an integrated approach, a 2-D } \\
\text { mathematical model has been } \\
\text { developed to sim-ulate the } \\
\text { extrusion of billets into round bars. }\end{array}$ \\
\hline 14. & $\begin{array}{l}\text { Optimization of Electrical } \\
\text { Resistance Spot Welding } \\
\text { and Comparison with } \\
\text { Friction Stir Spot Welding } \\
\text { of AA2024-T3 Aluminum } \\
\text { Alloy Joints }\end{array}$ & $\begin{array}{l}\text { R. Karthikeyan, } \\
\text { V. Balasubramaian. }\end{array}$ & $\begin{array}{l}\text { ERSW process parameters were } \\
\text { upgraded to attain the maximum } \\
\text { tensile shear fracture load (TSFL) of } \\
\text { the joints using response surface } \\
\text { methodology. } \\
\text { It was observed that the friction stir } \\
\text { spot welding joints yielded high } \\
\text { Tensile shear fracture load } \\
\text { compared to Electrical resistance } \\
\text { spot welding. }\end{array}$ \\
\hline 15. & $\begin{array}{l}\text { FEM analysis of fiber laser } \\
\text { welding of Titanium and } \\
\text { Aluminum }\end{array}$ & $\begin{array}{l}\text { Giuseppe Casalino, } \\
\text { Michelangelo } \\
\text { Mortello, Patrice } \\
\text { Peyre }\end{array}$ & $\begin{array}{l}\text { In this study, the thermal simulation } \\
\text { of fiber laser autogenouswelding of } \\
\text { Ti6Al4V joints and AA5754-T40 } \\
\text { joints in butt } \\
\text { configuration was processed by } \\
\text { FEM analysis. The following } \\
\text { observations are: } \\
\text { A good agreement between } \\
\text { experimental and numerical results } \\
\text { was shown by the comparison of } \\
\text { temperatures and thermal cycles. } \\
\text { The model obtained was capable to } \\
\text { predict the thermal behavior of metal } \\
\text { joints performed by traditional laser } \\
\text { welding and fibre laser welding }\end{array}$ \\
\hline 16. & $\begin{array}{l}\text { Numerical analysis of } \\
\text { thermal fluid transport }\end{array}$ & $\begin{array}{l}\text { Cheng-cai LIU, } \\
\text { Jing-shan HE }\end{array}$ & $\begin{array}{l}\text { 1) A } 2 \mathrm{D} \text { mathematical model has } \\
\text { been proposed to detect the coupled }\end{array}$ \\
\hline
\end{tabular}




\begin{tabular}{|c|c|c|c|}
\hline & $\begin{array}{l}\text { behavior during electron } \\
\text { beam welding of } 2219 \\
\text { aluminum alloy plate }\end{array}$ & & $\begin{array}{l}\text { transport behavior } \\
\text { thermalfluidduring electron beam } \\
\text { welding of } 20 \mathrm{~mm} \text {-thick aluminum } \\
\text { alloy. } \\
\text { 2) The accord between the } \\
\text { theoretical results and the } \\
\text { experimental results shows that the } \\
\text { proposed 2D numerical model is } \\
\text { practical for a description of } \\
\text { physical phenomena during EBW } \\
\text { process. } \\
\text { 3) The decreased heat flux of } \\
\text { electron beam well } \\
\text { simulated by the model shows the } \\
\text { gradual deceleration of keyholing } \\
\text { velocity and promotes the } \\
\text { emergence of quasi-stable state. } \\
\text { 4) As the keyholing depth increases, } \\
\text { the keyhole } \\
\text { instability is increased and further } \\
\text { drilling by beam energy is not } \\
\text { possible. }\end{array}$ \\
\hline 17. & $\begin{array}{l}\text { Numerical modelling } \\
\text { offrictionstirwelded } \\
\text { aluminium jointsunder high } \\
\text { rateloading }\end{array}$ & $\begin{array}{l}\text { Colin McAuliffe, } \\
\text { RyanKarkkainen , } \\
\text { Chian Yen , } \\
\text { HaimWaisman }\end{array}$ & $\begin{array}{l}\text { In this report } \\
\text { FrictionStirWelded(FSW)jointunder } \\
\text { Varioushighstrain load rating is } \\
\text { studied. } \\
\text { It was observed that early failure of } \\
\text { the stir welded joint is due to stress } \\
\text { concentrations at material zone inter- } \\
\text { faces, suggesting to adapt better } \\
\text { manufacturing methods to minimize } \\
\text { abrupt property changes. } \\
\text { This also suggests that FSW joint } \\
\text { strength can be increased by } \\
\text { minimization of interfacial stresses, } \\
\text { which can be done by certain } \\
\text { process modifications. }\end{array}$ \\
\hline 18. & $\begin{array}{l}\text { Optimization of friction stir } \\
\text { welding parameters for } \\
\text { improved } \\
\text { corrosionresistance } \\
\text { AA2219 aluminum alloy } \\
\text { joints }\end{array}$ & $\begin{array}{l}\text { G. Ram babu } \\
\text { BalajiNaik, } \\
\text { C.H.Venkatarao }\end{array}$ & $\begin{array}{l}\text { The results shows that the shape of } \\
\text { the pin has an important effect on } \\
\text { the joint structure and the corrosion } \\
\text { properties. } \\
\text { The hexagon tool profile was used to } \\
\text { obtain the best quality weld. } \\
\text { A mathematical model was proposed } \\
\text { to identify the corrosion resistances } \\
\text { of friction stir welded } \\
\text { aluminium alloy joints. } \\
\text { The optimized values closely match } \\
\text { the experimentally } \\
\text { determined values. }\end{array}$ \\
\hline
\end{tabular}




\begin{tabular}{|c|c|c|c|}
\hline 19. & $\begin{array}{l}\text { Prediction and optimization } \\
\text { of friction welding } \\
\text { parameters for } \\
\text { joining aluminium alloy and } \\
\text { stainless steel }\end{array}$ & $\begin{array}{l}\text { R.Paventhan,V.Bala } \\
\text { subramanian. }\end{array}$ & $\begin{array}{l}\text { A numerical relationship was } \\
\text { proposed to find the tensile strength } \\
\text { of friction welded aluminium alloy } \\
\text { and austenitic stainless steel } \\
\text { dissimilar joints, incorporating } \\
\text { process parameters. } \\
\text { A maximum tensile strength of } 213 \\
\text { MPa may be observed under the } \\
\text { welding conditions: } 80 \text { MPa of } \\
\text { friction pressure, } 80 \mathrm{MPa} \text { of forging } \\
\text { force, } \\
3 \text { s of friction time, } \\
\text { and } 3 \text { s of forging time. } \\
\text { The tensile strength of the joints was } \\
\text { greatly influenced by friction } \\
\text { pressure. }\end{array}$ \\
\hline 20. & $\begin{array}{l}\text { Numerical simulation and } \\
\text { experimental investigation } \\
\text { on friction stir welding of } \\
6061-\mathrm{T} 6 \text { aluminum alloy }\end{array}$ & $\begin{array}{l}\text { Jing Zhang, } \\
\text { Yifuxincheng. }\end{array}$ & $\begin{array}{l}\text { A new model which is very accurate } \\
\text { to the actual FSW process was } \\
\text { developed. } \\
\text { The temperature of each measured } \\
\text { points obtained by numerical } \\
\text { simulation is similar to the } \\
\text { experimental one. } \\
\text { It shows that during the FSW } \\
\text { process, material flow is a complex } \\
\text { behavior, and it has important effect } \\
\text { on the } \\
\text { quality of the weld. }\end{array}$ \\
\hline
\end{tabular}

\section{SUMMARY}

Mathematical models are almost used by all engineering products. Models like computational fluid dynamics, finite element modelling, simulation models, process models,power grid models and so on. But then, the construction of mathematical models is not clearly understood by everyone. The major problem is that not all models are precise and represent reality. And so models always diverge in some factor and are inaccurate. Hence estimation of model error is the key to promote error free models.

Here, a feasible survey has been conducted to identify if mathematical models can be used for numerical simulation of different types of welding in aluminium alloys.

This type of modelling is an interdisciplinary subject. Mathematicians share their level of expertise to obtain better results for the overall development of models. There are many particular reasons for the importance of modelling, but most are related in some ways to the following:

Important to gain understanding:

If we have a mathematical model which shows the necessary behavior of a real-world domain of interest, we can understand that system properly through a numerical analysis of the model. Furthermore, in the process of creating the model we find out which factors are most significant in the system, and how the various aspect of the system is connected.

Important to predict, or forecast, or simulate: 
Most of the time, we wish to know what a real world domain will do in the future, but it is impossible, impractical, and very expensive to do experiments directly with such domains.

\section{CONCLUSION}

It is concluded that the weldability characteristics of aluminium alloys widely vary from alloy system to alloy system.Hot cracking or solidification shrinkage cracking tendency is the most important factor governing the weldability of aluminium alloys. Also the proper choice of filler material plays a major role in controlling solidification shrinkage. The current survey has been carried out to assess the mathematical models for obtaining the mechanical properties and metallurgical properties of welds.

It was also concluded that the ratio of tensile strength,joint efficiency and corrosion resistance abilities can be proposed by such models. The friction stir welding is mostly preferred when joining aluminium alloys of various constituents. All the mathematical models developed to obtain various characteristics of the weld joints resulted with $95 \%$ confidence level.

The simulated algorithms has been used to optimize thefriction stir welding parameters to obtain maximum results in welded joints. The welding parameters like the laser power, welding speed, and power intensity were all investigated.

\section{REFERENCES}

[1]Qiang Li, Chris Harris, Mark R.Jolly, -Finite element modelling simulation of transverse welding phenomenon in aluminium extrusion process.

[2]G.Elatharasan,V.S. Senthil Kumar.-An experimental analysis and optimization of process parameter on friction stir welding of AA 6061-T6 aluminum alloy using RSM.

[3]R. Palanivel, P. Koshy Mathews and N. Murugan-Development of mathematical model to predict the mechanical properties of friction stir welded AA6351 aluminum alloy.

[4]N. Sonti and M. F. Amateau-Finite element modelling of heat flow in deep penetration laser welds in aluminium alloys.

[5]N. Kamp, A.Sullivan, J.D. Robson-Modelling of friction stir welding of 7xxx aluminium alloys.

[6]Kevin J.Colligana, Rajiv S. Mishra-A conceptual model for the process variables related to heat generation in friction stir welding of aluminium.

[7]M. A. Wells, D. M. Maijer, S. Jupp, G. Lockhart and M. R. van der Winden-Mathematical model of deformation and microstructural evolution during hot rolling of aluminium alloy 5083 .

[8]X. SUN AND P. DONG-Analysis of Aluminum Resistance Spot

Welding Processes Using Coupled Finite Element Procedures.

[9]M.Balasubramanian,V.Jayabalan,V.Balasubramanian-Developing mathematical models to predict tensile properties of pulsed current gas tungsten arc welded 6Al-4V-Ti alloy.

[10]K. Elangovan , V. Balasubramanian , S. Babu -Predicting tensile strength of friction stir welded AA6061 aluminium alloy joints by a mathematical model.

[11]S.Sreesabari ,S.Malarvizhi,V.Balasubramanian- Experimental and numerical investigation on under-water friction stir welding of armour grade AA2519-T87 aluminium alloy.

[12]HuijieZhang ,Huijie Liu-Mathematical model and optimization for underwater friction stir welding of a heat-treatable aluminum alloy 
[13] YahyaMahmoodkhania, Mary A. Wells, Nick Parson, W.J. Poole-Numerical modelling of the material flow during extrusion ofaluminium alloys and transverse weld formation.

[14]R. Karthikeyan,V. Balasubramaian-Optimization of Electrical Resistance Spot Welding and Comparison with Friction Stir Spot Welding of AA2024-T3 Aluminum Alloy Joints.

[15]Giuseppe Casalino, Michelangelo Mortello, Patrice Peyre-FEM analysis of fiber laser welding of Titanium and Aluminum.

[16]Cheng-cai LIU, Jing-shan HE-Numerical analysis of thermal fluid transport behavior during electron beam welding of 2219 aluminum alloy plate.

[17]Colin McAuliffe , RyanKarkkainen, Chian Yen , HaimWaisman-Numerical modelling of friction stir welded aluminium joints under high rate loading.

[18]G. Ram babu ,BalajiNaik, C.H.Venkatarao -Optimization of friction stir welding parameters for improved corrosionresistance of AA2219 aluminum alloy joints.

[19]R.Paventhan,V.Balasubramanian-Prediction and optimization of friction welding parameters for joining aluminium alloy and stainless steel

[20]Jing Zhang, Yifuxincheng-Numerical simulation and experimental investigation on friction stir welding of 6061-T6 aluminum alloy

[21]Elangovan K, Balasubramanian V. Influences of pin profile and rotational speed of the tool on the formation of friction stir processing zone in AA2219 aluminium alloy. Mater SciEng - A 2007;459:19-34.

[22] Elangovan K, Balasubramanian V. Effect of tool pin profile and axial force on the formation of friction stir processing zone in AA6061 aluminium alloy. Int J AdvManufTechnol in press.

[23] Box GEP, Hunter WH, Hunter JS. Statistics for experiment. New York: John Wiley Publications; 1978.

[24] Miller I, Freund JE, Johnson. Probability and statistics for engineers. New Delhi: Prentice of Hall of India; 1999.

[25] Elangovan K, Balasubramanian V. Effect of pin profile and rotational speed of the tool on the formation of friction stir processing zone in AA6061 aluminium alloy. J Mater ManufProcesses, in press.

[26] Won Bae Lee. Mechanical properties related to microstructural variation of 6061 aluminium alloy joints by friction stir welding. Mater Trans2004;45(5): 